\title{
Does hyperthermia increase apoptosis in white spot syndrome virus (WSSV)-infected Litopenaeus vannamei?
}

\author{
Clarissa B. Granja*, Luis Fernando Aranguren, Oscar M. Vidal, Lacides Aragón, Marcela Salazar \\ Corporación Centro de Investigación de la Acuicultura de Colombia (CENIACUA), Carrera 8a \# 96-60, Bogotá, Colombia
}

\begin{abstract}
Apoptosis plays a critical role in development and maintenance of multicellular organisms. It has also been described as an anti-viral mechanism in both insects and vertebrates. In fact, to escape the immune system and to increase their spread, some viruses such as baculovirus produce antiapoptotic molecules. Conversely, a recent report showing a positive correlation between the number of apoptotic cells and the severity of white spot syndrome virus (WSSV) infection in Penaeus monodon suggested that apoptosis might be the cause of death in viral-infected shrimp. Searching for the mechanisms involved in the beneficial effect of hyperthermia for WSSVinfected Litopenaeus vannamei (also called Penaeus vannamei) and considering that hyperthermia increases apoptosis in other experimental models, we investigated the presence of apoptosis by Tdt-mediated dUTP nick-end label (TUNEL), from 4 of $168 \mathrm{~h}$ in 3 groups of $50 \mathrm{~L}$. vannamei juveniles. Group 1 consisted of experimentally infected shrimp (intramuscular injection of $3 \times 10^{7}$ viral copies) kept at $25^{\circ} \mathrm{C}$, Group 2 of similarly infected shrimp kept at $32^{\circ} \mathrm{C}$ and Group 3 of uninjected shrimp kept at $32^{\circ} \mathrm{C}$. Apoptosis was found only in WSSV-infected individuals. Shrimp at $25^{\circ} \mathrm{C}$ were positive for apoptotic cells in $48(16 \%)$ of their examined tissues or organs, compared to $62(21 \%)$ for those at $32^{\circ} \mathrm{C}$. Moreover, shrimp at $32^{\circ} \mathrm{C}$ also had a significantly higher overall mean apoptotic index (AI) than shrimp at $25^{\circ} \mathrm{C}$ $(\mathrm{p}<0.05)$. Comparison of mean AI at 72,96 and 120 h postinfection showed that individuals at $32^{\circ} \mathrm{C}$ presented a significantly higher values than those at $25^{\circ} \mathrm{C}$. These results suggested that hyperthermia might facilitate apoptosis in WSSV-infected $L$. vannamei and might be one of the mechanisms responsible for increased survival of infected shrimp maintained at $32^{\circ} \mathrm{C}$.
\end{abstract}

KEY WORDS: Apoptosis - White spot syndrome virus . Hyperthermia · Litopenaeus vannamei

Resale or republication not permitted without written consent of the publisher

Apoptosis is the genetically regulated mechanism by which individual cells orchestrate their own deletion in normal and diseased tissues (Kerr et al. 1972, Soini et al. 1998). Its initial description was based on typical morphological features such as shrunken organelles, condensed chromatin, formation of apoptotic bodies and absence of inflammation in the adjacent areas (Kerr et al. 1972, Wyllie et al. 1980).
In the last decade, many components of the apoptotic machinery have been characterized in vertebrates and invertebrates, elucidating part of the biochemical events that underlie the morphological alterations (Hengartner 2000). Apoptosis is mediated by the sequential activation of cysteine proteases or caspases that cleave other caspases and noncaspase substrates such as proteins of the DNA repair system and of the cytoskeleton (Nicholson 1999). This process generates structural and functional modifications related to cell death, including stepwise double-stranded DNA fragmentation that is considered the biochemical hallmark of apoptosis.

Apoptosis is essential in both the development and homeostasis of multicellular organisms and many of its components are remarkably conserved from worms to humans (Bergmann et al. 1998). Regarding the immune response, apoptosis has been described as an effector mechanism in invertebrates (Clem \& Miller 1993, 1994), while in mammals it regulates the adaptive response (Koyama et al. 2000). Apoptosis has been proposed as the main anti-viral mechanism in invertebrates (Koyama et al. 2000). Studies on insect cell lines infected with mutant baculoviruses and adenoviruses suggested that the major significance of apoptosis is an abortion of viral multiplication by premature lysis of the infected cells (Pilder et al. 1984, Clem \& Miller 1993). Other experimental models showed that several distinct viruses have developed mechanisms to block premature apoptosis of infected cells in order to prolong cell survival and to guarantee the production of viral progeny (Roulston et al. 1999).

Recently, we described a beneficial effect of hyperthermia upon the survival of WSSV-infected Litopenaeus vannamei (also called Penaeus vannamei) but the underlying mechanism is still unknown (Vidal et al. 2001). Taking into account that apoptosis is involved in the invertebrate antiviral response and that hyperthermia facilitates apoptosis in mammalian experimental 
models (Hermisson et al. 2000, Yamamoto et al. 2000), we investigated the presence of apoptosis in WSSVinfected $L$. vannamei maintained at ambient temperature and in heated tanks. In this study, apoptotic cells were detected by TdT-mediated-dUTP-NickEnd-Labeling (TUNEL), which measures nuclear DNA fragmentation.

Materials and methods. Experimental individuals and conditions: Litopenaeus vannamei utilized in these experiments were bred in captivity at CENIACUA's facilities located in Cartagena, Colombia (Atlantic Coast). Before the trials, they were acclimated for $20 \mathrm{~d}$ in the CENIACUA Bioassay Laboratory, Tumaco, Colombia (Pacific Coast). To rule out the presence of WSSV prior experimental infection, pleopods from 30 shrimp from the same batch (full siblings) were tested by nested PCR (Lo et al. 1996). Experimental infection was performed by injection of $0.1 \mathrm{ml}(3 \times$ $10^{7}$ viral copies determined by real time PCR) (TangNelson \& Lightner 2001) of our WSSV inoculum at the 4 th abdominal segment, as previously reported (Vidal et al. 2001).

Shrimp of 1 to $2 \mathrm{~g}$ average weight were maintained in $40 \mathrm{l}$ plastic tanks (10 individuals per tank) containing chlorinated and filtered seawater, 29 ppt salinity, under constant aeration and with $100 \%$ daily water exchange. The 2 water temperature regimens used in tanks were $24.9 \pm 0.5^{\circ} \mathrm{C}$ (ambient temperature, hereinafter referred to as $25^{\circ} \mathrm{C}$ ) and $31.6 \pm 2^{\circ} \mathrm{C}$ (hereinafter referred to as $32^{\circ} \mathrm{C}$ ) maintained with immersion heaters (Aquarium system VISI Therms Vtn 100, VISI Therm Tecnology). The shrimp were fed twice a day with a commercial shrimp diet (Purina $25 \%$ protein).

Experimental design: We studied 3 groups of 50 WSSV-free Litopenaeus. vannamei. At Day 0, shrimp from Group 1 were injected with WSSV and kept (10 in each tank) at ambient temperature $\left(25^{\circ} \mathrm{C}\right)$. Group 2 was also injected with WSSV but maintained at $32^{\circ} \mathrm{C}$. Group 3 consisted of healthy uninjected individuals kept at $32^{\circ} \mathrm{C}$.

Five shrimp each ( 1 from each tank of each group) were sacrificed and fixed at $4,6,18,24,48,72,96,120$, 144 and $168 \mathrm{~h}$ after infection. Due to the WSSV infection in the shrimp at $25^{\circ} \mathrm{C}, 8$ individuals died before they could be sampled; therefore, this group was evaluated up to $120 \mathrm{~h}$ only. In this group, we also studied 2 extra moribund individuals fixed at 75 and $92 \mathrm{~h}$ post infection. All samples were preserved in Davidson's fixative for $24 \mathrm{~h}$ and then transferred to $70 \%$ ethanol until processing as previously described (Bell \& Lightner 1988). Routine histopathology (Bell \& Lightner 1988) was performed on all samples to rule out concomitant diseases and to verify WSSV infection status. Infections were considered H\&E positive when they showed typical WSSV histopathological features in- cluding hypertrophied nuclei with basophilic inclusions in the cuticular epithelium, connective tissue, antennal gland, lymphoid organ and/or hematopoietic tissue (Lightner 1996). In addition, selected samples from each time point were also analyzed using an in situ hybridization assay for WSSV (DiagXotics). Although we did not find mortalities within the individuals kept at $32^{\circ} \mathrm{C}, 7$ shrimp from Group 2 and 1 shrimp from Group 3 were excluded from this study due to the presence of concomitant diseases such as hepatopancreatic parvovirus and vibrosis. Thus, the total number of assayed shrimp was 42, 43 and 49 from Groups 1, 2 and 3 , respectively.

Detection of apoptotic cells: We used the DeadEnd $^{\mathrm{TM}}$ Colorimetric Apoptosis Detection System (Promega) following the manufactor's protocol, except for increasing the hydrogen peroxide concentration from 0.3 to $6 \%$ to improve the blocking of endogenous peroxidases. The TUNEL assay is based on the incorporation of a biotinylated nucleotide at the $3^{\prime}-\mathrm{OH}$ end of fragmented DNA by the enzyme terminal deoxynucleotidyl transferase. These nucleotides are detected by the addition of horseradish-peroxidase-labeled streptavidin and the chromogen substrate diaminobenzidine that stain the apoptotic nuclei brown. After developing, slides were counterstained with Methyl Green (Vector Laboratories) for $1 \mathrm{~min}$ at $56^{\circ} \mathrm{C}$, rinsed with deionized water and mounted in VectaMount ${ }^{\mathrm{TM}}$ (Vector).

Two researchers independently counted the number of positive cells in 10 high power magnification fields $(400 \times)$ for each organ or tissue (de Jong et al. 2000). These included antennal gland, gills, hepatopancreas, lymphoid organ, heart, stomach, muscle, cuticular epithelium, connective tissue and pericardium for each shrimp. The apoptotic index was determined as the total number of apoptotic cells per shrimp (the sum of apoptotic cells in all high power fields analyzed for each individual. The mean apoptotic index represents the average of the apoptotic index from the 5 shrimp studied per time point. Statistical analysis was performed using ANOVA and Student's t-test.

Results and discussion. The presence or absence of WSSV in tissues from experimental individuals was determined (Table 1) by routine histopathology (Lightner 1996) and by detection of WSSV DNA using in situ hybridization. Overall, a much higher percentage of WSSV infected shrimp showing typical WSSV nuclear inclusions was found at $25^{\circ} \mathrm{C}$ (i.e. $62 \%$ in Group 1) than at $32^{\circ} \mathrm{C}$ (i.e. $16 \%$ in Group 2). No WSSV inclusions were found in control Group 3 at $32^{\circ} \mathrm{C}$. In situ hybridization revealed similar results with $54 \%$ positive specimens in Group 1 and $18 \%$ in Group 2 while Group 3 was negative. Many shrimp samples collected from challenge groups in the early stages of infection gave 
Table 1. WSSV infecting Litopenaeus vannamei. Diagnosis of WSSV infection by hematoxilin-eosin (H\&E) staining and by in situ hybridization in WSSV-challenged shrimp at 25 or $32^{\circ} \mathrm{C}$ and in unchallenged

\begin{tabular}{|lccc|}
\hline Diagnostic test & $\begin{array}{c}\text { Group } 1 \\
\left(25^{\circ} \mathrm{C}\right)\end{array}$ & $\begin{array}{c}\text { WSSV positive } \\
\text { Group 2 } \\
\left(32^{\circ} \mathrm{C}\right)\end{array}$ & $\begin{array}{c}\text { Group 3 } \\
\left(32^{\circ} \mathrm{C}\right)\end{array}$ \\
\hline H\&E staining & & & \\
n positive/n total & $26 / 42$ & $8 / 43$ & $0 / 49$ \\
$\%$ positive & 62 & 16 & 0 \\
Positive time points & 18 to $120 \mathrm{~h}$ & 6 to $48 \mathrm{~h}$ & 0 \\
In situ hybridization & & & 0 \\
$\mathrm{n}$ positive/n total & $13 / 24$ & $5 / 27$ & 0 \\
$\%$ positive & 54 & 18 & 0 \\
Positive time points & 24 to $120 \mathrm{~h}$ & 45 to $48 \mathrm{~h}$ & 0 \\
\hline
\end{tabular}
control shrimp at $32^{\circ} \mathrm{C}$. n: number of samples

apoptotic cells. Moreover, apoptosis is not sufficient to eliminate the virus because reducing the water temperature for WSSVinfected shrimp that had been kept in heated tanks for $20 \mathrm{~d}$ resulted in mortality (data not shown).

After $48 \mathrm{~h}$ of infection, the mean AI of Group 1 started to increase, reaching the highest level at $120 \mathrm{~h}$ (Fig. 2). This increase in AI observed at the final stages of disease is consistent with the only report on apoptosis in WSSV-infected shrimp (Sahtout et al. 2001). These authors also found that intranuclear inclusion bodies were positive by fluorescent TUNEL in typical WSSV infected cells. In contrast, the apoptotic cells detected by us (colorimetric TUNEL) did not present negative in situ hybridization results but all Group 1 shrimp examined after $48 \mathrm{~h}$ post-infection were positive. In Group 2, the number cells positive by in situ hybridization was always less than in Group 1, regardless of sampling time. At early stages of infection, the low number of positive cells might have been due to initially undetectable WSSV induced alterations. Conversely, negative results beyond $72 \mathrm{~h}$ post-infection in shrimp at $32^{\circ} \mathrm{C}$ indicated that temperature affected the course of the disease.

Apoptotic cells were detected only in infected shrimp (Groups 1 and 2). Up to $120 \mathrm{~h}$ post infection, individuals from Group 1 were positive in $48(16 \%)$ of their examined tissues or organs, while Group 2 had 62 $(21 \%)$ positive sites. The apoptotic cells showed a shrunken, dark brown nucleus and a pale green cytoplasm (Fig. 1). These cells were not found in unchallenged shrimp maintained in tanks at $32^{\circ} \mathrm{C}$ (Group 3), indicating that hyperthermia by itself did not induce apoptosis.

Fig. 2 shows the mean Apoptotic Index (AI) over time for Group $1\left(25^{\circ} \mathrm{C}\right)$ and Group $2\left(32^{\circ} \mathrm{C}\right)$. The mean AI were always higher in Group 2 than in Group 1 and statistically significant differences were observed at 72, 96 and $120 \mathrm{~h}$ post-infection (ANOVA, p < 0.05). Furthermore, comparison of the mean of $8 \mathrm{AI}$ means for each group ( 4 to $120 \mathrm{~h}$ ) showed that the overall mean for shrimp kept at $32^{\circ} \mathrm{C}$ was significantly higher than the mean for shrimp kept at $25^{\circ} \mathrm{C}$ (Student $t$-test, $\mathrm{p}<0.05)$. These data suggest that hyperthermia might facilitate the apoptotic process, which, in turn, could reduce viral replication and limit infection. Indeed, the shrimp held at $32^{\circ} \mathrm{C}$ showed a reduction in mean AI after $144 \mathrm{~h}$, a finding that might reflect a decrease in the number of infected cells. We believe that apoptosis is not the only mechanism responsible for increasing survival of WSSV-infected Litopenaeus vannamei kept at $32^{\circ} \mathrm{C}$, since all infected individuals analyzed had hypertrophied nuclei, characteristic of WSSV-infected cells (Lightner 1996). This discrepancy can be attributed, at least in part, to the high sensitivity of fluorescent dyes. However, the use of fluorescence does not permit the analysis of apoptotic cell morphology, increasing the risk of misinterpretation and false positive results due to necrosis, autolysis and tissue damage through processing (Labat-Moleur et al. 1998, Stadelmann \& Lassmann 2000).

Based on the histological findings, i.e. the absence of inflammatory response, it has been suggested that apoptosis is involved in the pathogenesis of WSSV infection and that it might be the cause of death in infected shrimp (Flegel \& Pasharawipas 1998). This hypothesis is supported by the results of Sahtout, that showed a positive correlation between the number of apoptotic cells and the severity of WSSV infection (Sahtout et al. 2001). Another study also shows a correlation between apoptosis and mortality in yellow head virus-infected Penaeus monodon and it is suggested that the high number of apoptotic cells may be the primary cause of death (Khanobdee et al. 2002). As reported (Sahtout et al. 2001), we found an increase of mean AI in WSSV-infected shrimp maintained at ambient temperature, but interestingly, this increment was lower than the one observed in individuals subjected to higher temperature conditions. Therefore, our data suggests that apoptosis is associated with survival of WSSV-infected shrimp. Our hypothesis is supported by the fact that apoptosis might be an important antiviral mechanism in insects (Clem \& Miller 1993, 1994, Koyama et al. 2000) and that some viruses produce anti-apoptotic molecules such as p35 and IAP (Clem 2001, Roulston et al. 1999) in order to escape it. However, further investigations about the apototic routes in Litopenaeus vannamei and their interactions with WSSV molecules are needed to resolve this issue. 


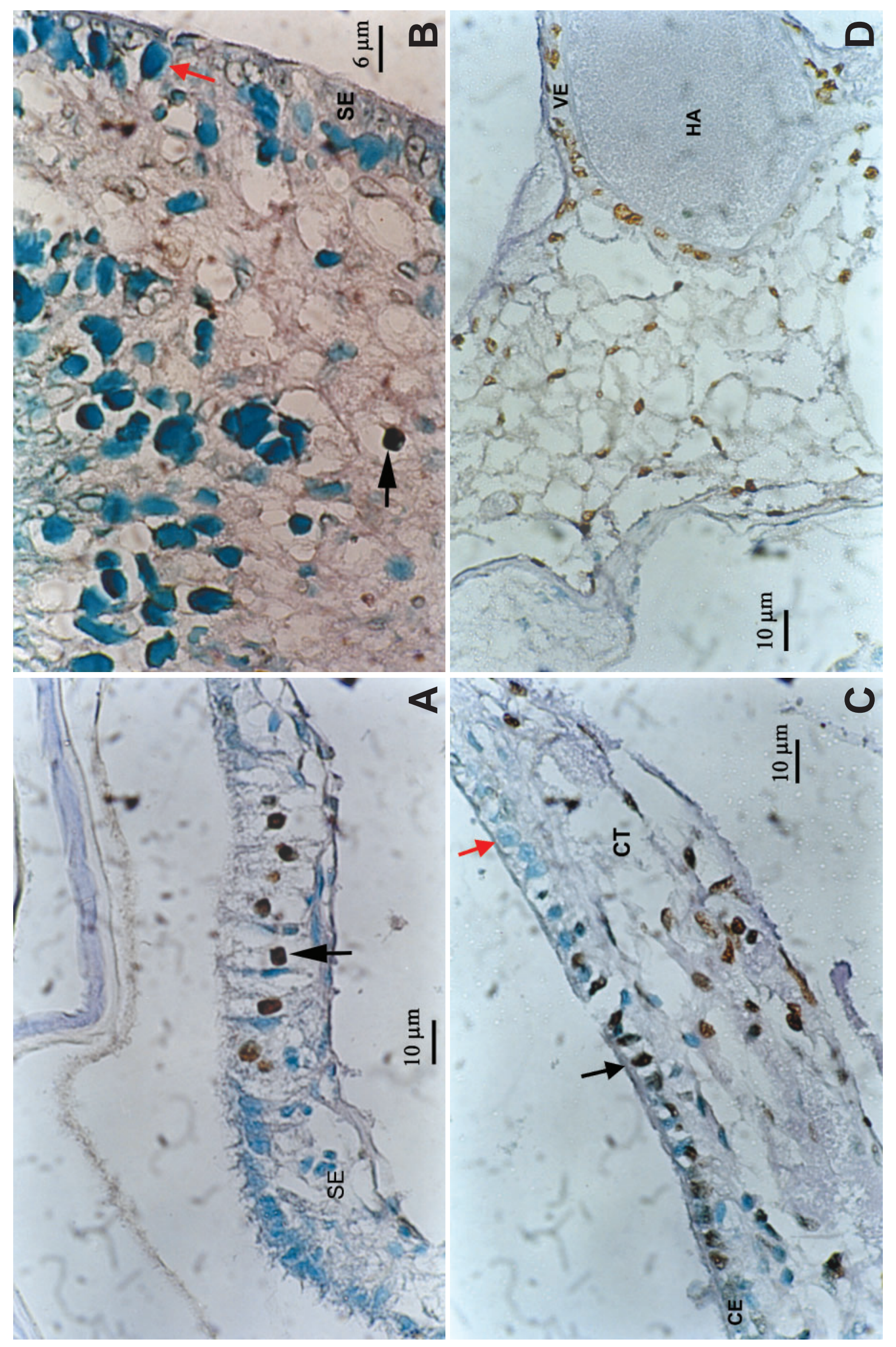

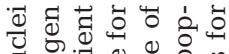

द्व

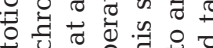

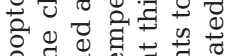

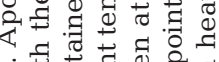

बं

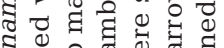

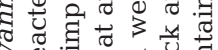

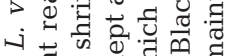

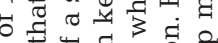

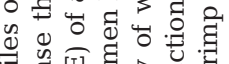

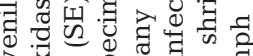

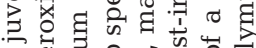

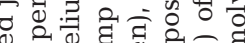

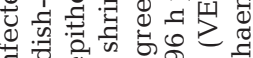

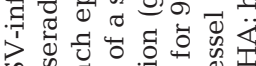

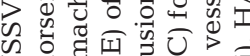

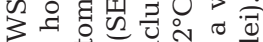

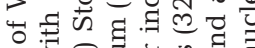

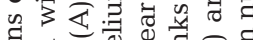

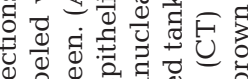

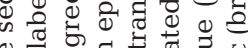

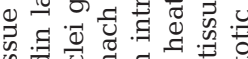

记

듄 문

诘 운

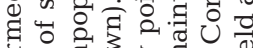

응 0 负

ه

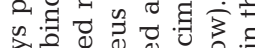

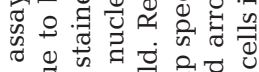

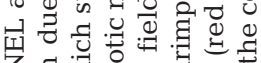

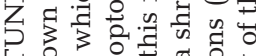

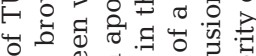

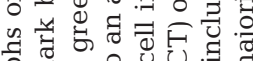

응 주의

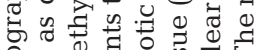

o 0 a

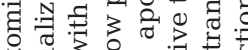

웅

讨

I 3 w

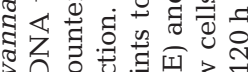

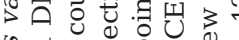

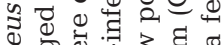

व

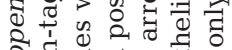

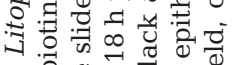

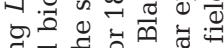

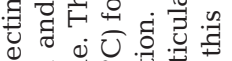

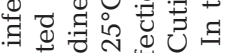

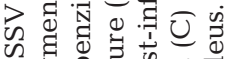

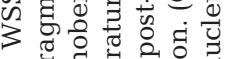

-

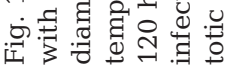




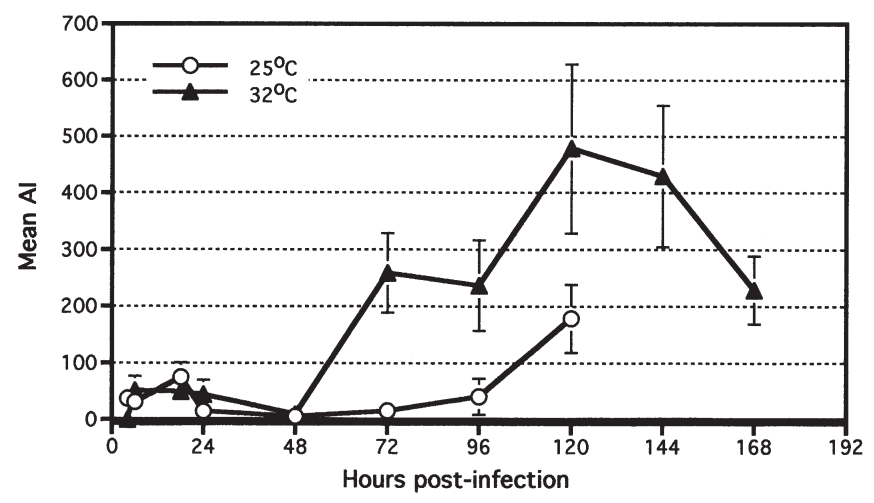

Fig. 2. WSSV infecting Litopenaeus vannamei. Shrimp from each group $\left(25\right.$ and $\left.32^{\circ} \mathrm{C}\right)$ were collected at different time points after WSSV infection. The apoptotic index (AI) shown at each sampling time is the mean AI of 5 shrimp from each group

Looking at the distribution of apoptotic cells in tissues or organs from all individuals of each group, we found that cuticular epithelium ( $40 \%$ ) was the preferential site at $25^{\circ} \mathrm{C}$, while connective tissue $(34 \%)$ was the preferential site at $32^{\circ} \mathrm{C}$ (Fig. 3). In both groups, cells undergoing apoptosis were detected within WSSV target tissues (Lightner 1996) and in hepatopancreatic interstitial cells, as described before (Sahtout 2001). These results indicate that WSSV is necessary to induce apoptosis, either indirectly by eliciting a host response (Clem \& Miller 1993, 1994) or directly via a viral mediated mechanism (Roulston et al. 1999).

In summary, the significant increase in number of apoptotic cells in shrimp kept at $32^{\circ} \mathrm{C}$ suggests that hyperthermia facilitates apoptosis in WSSV-infected Litopenaeus vannamei. This would reduce viral replication, allowing the shrimp to control the disease and survive. This hypothesis is supported by previous

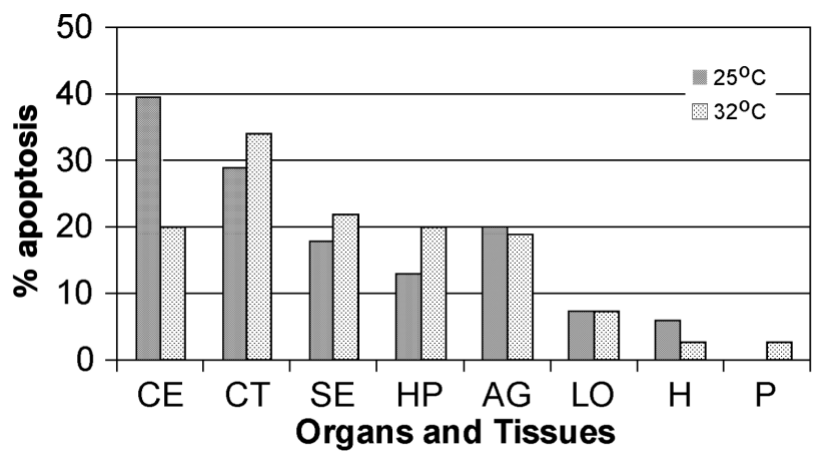

Fig. 3. WSSV infecting Litopenaues vannamei. Percentage of WSSV-infected shrimp kept at $25^{\circ} \mathrm{C}$ (Group 1) and $32^{\circ} \mathrm{C}$ (Group 2) showing evidence of apoptosis in various organs and tissues by TUNEL assay. AG: anthenal gland; CE: cuticular epithelium; CT: connective tissue; H: hearth; HP: hepatopancreas; LO: lymphoid organ; P: pericardium; SE: stomach epithelium reports showing that hyperthermia induces apoptosis by enhancing cytochrome $c$ release in human glioma cells (Hermisson et al. 2000) and by redistribution of Bax in rat testes (Yamamoto et al. 2000). However, further research is needed to establish the role of these and other molecules in the shrimp apoptotic routes and the interactions between virus and host in this context.

Acknowledgements. The authors wish to thank Dr. Tang, from Dr. Lightner's Laboratory, for the viral quantification of our inoculum by real time PCR and Drs. Maria Mercedes Zambrano and James Cock for valuable comments and suggestions for this manuscript. This research was supported by the following Colombian agencies: Servicio Nacional de Aprendizaje SENA, Colciencias and the Ministry of Agriculture.

\section{LITERATURE CITED}

Bell TA, Lightner DV (1988) A handbook of normal penaeid shrimp histology. Special publication of the World Aquaculture Society, Baton Rouge, LA

Bergmann A, Agapite J, Steller H (1998) Mechanisms and control of programmed cell death in invertebrates. Oncogene 17:3215-3223

Clem RJ (2001) Baculoviruses and apoptosis: the good, the bad, and the ugly. Cell Death Differ 8:137-143

Clem RJ, Miller LK (1993) Apoptosis reduces both the in vitro replication and the in vivo infectivity of a baculovirus. J Virol 67:3730-3738

Clem RJ, Miller LK (1994) Control of programmed cell death by the baculovirus genes p35 and IAP. Mol Cell Biol 14: $5212-5222$

de Jong JS, van Diest PJ, Baak JPA (2000) Number of apoptotic cells as a prognostic marker in invasive breast cancer. Br J Cancer 82:368-373

Flegel TW, Pasharawipas T (1998) Viral accommodation: a new concept for crustacean response to viral pathogens. In: Flegel TW (ed) Advances in shrimp biotechnology. National Center for Genetic Engineering and Biotechnology, Bangkok, p 245-250

Hengartner MO (2000) The biochemistry of apoptosis. Nature 407:769-776

Hermisson M, Wagenknecht B, Wolburg H, Glaser T, Dichgans J, Weller M (2000) Sensitization of CD95 ligandinduced apoptosis in human glioma cells by hyperthermia involves cytocrome c release. Oncogene 19:2338-2345

Kerr JFR, Wyllie AH, Currie AR (1972) Apoptosis: a basic biological phenomenon with wide-ranging implications in tissue kinetics. Br J Cancer 26:239-257

Khanobdee K, Soowannayan C, Flegel TW, Ubol S, Withyachumnarnkul B (2002) Evidence for apoptosis correlated with mortality in giant black tiger shrimp Penaeus monodon infected with yellow head virus. Dis Aquat Org 48: 79-90

Koyama AH, Fukumori T, Fujita M, Irie H, Adachi A (2000) Physiological significance of apoptosis in animal virus infection. Microbes Infect 2:1111-1117

Labat-Moleur F, Guillermet C, Lorimier P, Robert C, Lantuejoul S, Brambilla E, Negoescu A (1998) TUNEL apoptotic cell detection in tissue sections: critical evaluation and improvement. J Histochem Cytochem 46:327-334

Lightner DV (1996) A handbook of shrimp pathology and 
diagnostic procedures for diseases of cultured penaeid shrimp. The World Aquaculture Society, Baton Rouge, LA

Lo CF, Leu JH, Ho CH, Chen CH and 8 others (1996) Detection of baculovirus associated with white spot syndrome (WSBV) in penaeid shrimp using polymerase chain reaction. Dis Aquat Org 25:133-141

Nicholson DW (1999) Caspase structure, proteolytic substrates and function during apoptotic cell death. Cell Death Differ 6:1028-1042

Pilder S, Logan J, Shenk T (1984) Deletion of the gene encoding the adenovirus 5 early region 1B 21,000-molecular weight polypeptide leads to degradation of viral and host cell DNA. J Virol 52:664-671

Roulston A, Marcellus RC, Branton PE (1999) Virus and apoptosis. Annu Rev Microbiol 53:577-628

Sahtout AH, Hassan MD, Shariff M (2001) DNA fragmentation, an indicator of apoptosis, in cultured black tiger shrimp Penaeus monodon infected with white spot syndrome virus (WSSV). Dis Aquat Org 44:155-159

Soini Y, Pääkkö P, Lehto VP (1998) Histopathological evaluation of apoptosis in cancer. Am J Pathol 153:1041-1053

Editorial responsibility: Timothy Flegel,

Bangkok, Thailand
Stadelmann C, Lassmann H (2000) Detection of apoptosis in tissue sections. Cell Tissue Res 301:19-31

Tang-Nelson K, Lightner DV (2001) Development of real-time PCR assays for detection of white spot syndrome virus, yellow head virus, Taura syndrome virus, and infectious hypodermal and hematopoietic necrosis virus in penaeid shrimp. Grant Report NA06FD0448. National Marine Fisheries Service, Long Beach, CA (also available at www.nmfs.noaa.gov/sfweb/sk/saltonsstallken/whitespot_ final.PDF

Vidal OM, Granja CB, Aranguren F, Brock JA, Salazar M (2001) A profound effect of hyperthermia upon the survival of $L$. vannamei juveniles infected with the WSSV. J World Aquacult Soc 32:364-372

Wyllie AH, Kerr JF, Currie AR (1980) Cell death: the significance of apoptosis. Int Rev Cytol 68:251-306

Yamamoto CM, Hikim APS, Huynh PN, Shapiro B, Lue Y, Salameh WA, Wang C, Swerdloff RS (2000) Redistribution of Bax is an early step in apoptotic pathway leading to germ cell death in rats, triggered by mild testicular hyperthermia. Biol Reprod 63:1683-1690

Submitted: July 2, 2002; Accepted: December 4, 2002

Proofs received from author(s): February 24, 2003 